\title{
Appraisal of the Influence of Agriculture on Economic Growth: Empirical Evidence from Nigeria
}

\author{
${ }^{1}$ K. E. Uma, ${ }^{2}$ F. E. Eboh $\&{ }^{3}$ P. C. Obidike \\ ${ }^{1}$ (Department of Economics \& Development Studies, Federal University, Ndufu Alike-Ikwo, Ebonyi State, \\ Nigeria, \\ ${ }^{2}$ (Department of Management, Abia State University, Uturu, Nigeria. \\ ${ }^{3}$ (Department of Banking and Finance, Abia State University, Uturu, Nigeria.
}

\begin{abstract}
The study focused on assessing the effect of agriculture on Nigeria's economic growth from 19702009. It examined the influence of output of various types of agricultural practices on real gross domestic product (rgdp), a proxy for economic growth. Data for the study were sourced from the [1]. Augmented DickeyFuller and Phillips Perron tests were carried out to test for unit-root and Johansen co-integration test confirmed a long-run relationship of the dependent and independent variables. Error correction model was established. The method of ordinary least square was employed in the data analysis. The study found that the contributions of crop production, livestock and fishing on economic growth were statistically insignificant. Only forestry contributed significantly to growth at the period of study. However, the combined effect of the variables was significant. On this note, among the recommendations made are that it is imperative for the federal, state and local governments to establish integrated agriculture in all the wards in each local government; corruption should be tackled, and there is need for emulation of the radical reform of food production adopted by the Chinese government.
\end{abstract}

Key words: Appraisal, influence, agriculture, economic growth, empirical evidence.

\section{Introduction}

Nigeria, at independence was an agrarian economy, feeding and generating income from the products of agriculture and exporting her surplus output to other countries of the world. The major reason was that Nigeria gave much attention to this important sector and also is highly bestowed with fertile soil that is conducive for varieties of crops production and other forms of agricultural practices. Actually, agriculture has been the main stay of the Nigerian economy as it was contributing greatly to the aggregate gross domestic product. Agriculture, sustained the Nigerian economy at independence. Its contribution to the gross domestic product in 1960/61 was 76 per cent, in 1990, it was 39.0 per cent; and it fell to $28.35 \%$ in 2002 ([2], [3]).

However, with the discovery of oil in commercial quantity there was a turnaround of the focused attention on agriculture, hence many Nigerians and the government shifted attention to the quick income flowing from oil sector referred to as Dutch disease. Consequently, aggregate output of agriculture began to fall and to the extent that the suppliers of food became the greater importers of food. Food importation rose from \$298.8 million in 1975 to $\$ 780.7$ million in 1977 , to $\$ 1,027.6$ million in 1978 and-stood at $\$ 1,437.5$ million in 1980. In 1999, food import bill stood at $\$ 103,489.8$ million, by 2009, it was $\$ 351,507.68$ million [1]. Besides, the available quantity of food supply become less than the demand, hence the prices of food rose.

[4] note that food crisis in Nigeria seems to have taken a dangerous dimension, taking into account the challenges presented by high prices of food. Agricultural commodity prices rose sharply since early 2006. Ever since, there has been a continued rise in food prices and the low income earners, the poor have not been able to cope, thereby retarding the living standard. This situation has raised poverty situation in the country. As a result, the production system of farmers, given their socio-economic situation, inconsistent government policies, poor infrastructural base and other factors combined to annihilate the sector thereby bringing in low production, high prices of food items, inflation, underdevelopment and poverty [5]. The high rate of unemployment and poverty in Nigeria are, to a great extent associated with neglect of agriculture.

There has been persistent increase in everything related to agricultural production in the country. A typical example is fertilizer, which was sold for an average of $\$ 141$ per bag in 1985 and $\$ 200$ in 1996, increased to 1,400 in 1997. At present it is over N2, 500. This gives rise to increase in the production cost and high cost of food items, with associated problems of malnutrition, household food insecurity and restricted access to nutritious and insufficient food, culminating in greater effects of poverty on many Nigerians ([5], [6], [7]). No wonder [8] recalled the report of ILO 1981 on Basic Needs Mission to Nigeria, lamented that the situation of stagnation of agricultural production arising from continuing backwardness of Nigeria agriculture has brought no significant improvement in the state of nutrition in the country 
Nevertheless, the Federal Government of Nigeria has come up with various programs and policies to ensure continuous food production in Nigeria. For instance, in 1972 the military leader, General Gowon established the National Accelerated Food Production Programme and the Nigeria Agricultural and Cooperative Bank under the implementation of Agricultural Development Projects (ADPS). In the same vein, in 1976, General Obasanjo instituted Operation Feed the Nation, and the Agricultural Credit Guarantee Scheme and Commodity Board of 1978. The civilian President Alhaji Shehu Shagairi introduced, the Green Revolution Programme, which was targeted or aimed at reducing food importation while at the same time, boosting crop and fibre production. In the same vein, the Buharia government, in 1983 introduced, Go-Back - to Land programme and other policies, among others ([9], [10]). Every leader in Nigeria has in one way or the other come up with policies and programmes to improve agricultural production but food shortage still persist. This presupposes that something is lacking and need to be addressed. Hence, this paper intends to come up with ways of tackling the shortcomings.

In this paper, it is our broad objective to empirically investigate the effect of agriculture on the growth of the Nigerian economy. Specifically, it is our intention to examine the effect of crop production (CP), livestock (LK), forestry (FT) and fishing (FS) on economic growth of Nigeria, measured by real gross product (RGDP). So, section one reviews related literature. Section two is the model formulation and method of data analysis. Result presentation/ discussion, recommendations and conclusion are in section three.

\section{Review Of Related Literature}

Nigeria has relied so much on agriculture after her independence in 1960, given its stage of economic development. The growth dynamics of the Nigerian economy have been propelled by the existence and exploitation of natural resources and primary products. At the onset, the agricultural sector was the base, as the country needed food and cash crops for advancement. Actually, Nigeria has been left by her contemporaries in the quest for development. A look at the Nigerian economy vis-a-vis that of China in recent past showed that, Nigeria was better in 1970. Nigeria had a GDP per capita of US $\$ 233.35$ and was ranked 88th in the world while China was ranked 114th with a GDP per capita of US\$111.82. But today, China is very far from Nigeria in terms of economic advancement [11]. The problem of 'growthlessness' can be attributed to inconsistent government policies, political instability, lack of creativity on the part of leaders, mismanagement of resources, under utilization of resources, brain drain, geometrical increase in population, lost of interest in agriculture as a means of livelihood, corruption, among others.

The abundance of food production and raw materials for industries were among the attraction of colonial masters to Nigeria. Subsistence farming was predominant and agriculture provided a large proportion of the population with easy source of livelihood. [12] points out that Agriculture has been the backbone of the Nigerian economy, providing employment and source of livelihood for the increasing population. It accounted for over half of the gross domestic product (gdp) of the Nigerian economy as at independence in 1960. Undoubtedly, one of the sources of national wealth and real income is essentially from agriculture. Consequently, development economists devoted much attention on how agriculture can best contribute meaningfully to aggregate economic expansion and modernization. However, in spite of the neglect of agriculture by the Nigerian government over the years, it remains the highest employer of labour in the country [13] .Over seventy per cent of Nigerians are into one form of agriculture or the other. However, subsistence farming is inadequate to provide required food consumption level of the large population of the country.

Really, many scholars have investigated on the agricultural situation in Nigeria and came up with varieties of remedial steps. One thing observed in Nigeria is not lack of policies and programmes rather the political will to implement and logically follow it to achieve the goal. In addition, there exist a lot of man-caused environmental problems debilitating agricultural practices in Nigeria. [14] notes that a lot of human activities like bush fallow, inappropriate technologies, overpopulation, transhumance, overgrazing, deforestation without adequate reforestation and profligate exploitation of mineral resources, are often not in tune with proper environmental management practices. Consequently, these bring about the increasing inability of the environment to provide the necessary sustenance to agricultural and rural development programs because of erosion, desertification and pollution. This is a critical situation that has imposed great challenges to agriculture in Nigeria over the years.

Besides, government capital expenditure on agriculture has been low and fluctuating. In 1970, the capital expenditure on agriculture and water resources was $\$ 5.6$ million, in 1980, it stood at 413.3 million, by 1990, it was $\$ 258.0$ million [15]. Over the years, it has been fluctuating and this considerably affected agricultural production in Nigeria.

[16] studied agriculture as an index of socio-economic development of Delta state of Nigeria employing descriptive statistics for the data analysis. They found among others that agricultural practice in Delta State is gender sensitive with more males than females participating in the sector. Besides, fish farming 
and live-stock production are falling, while crop farming is the major interest of the farmers. The swampy areas of Delta state are grossly underutilized with respect to agricultural productivity.

In their study of effects of agricultural reforms on the agricultural sector in Nigeria, [17] note that agriculture contributed minimally during the period in terms of output, market, foreign exchange and capital formation or transfer as a result of policy instability, poor coordination of policies, poor implementation and mismanagement of policy instruments and lack of transparency. Actually, they pinpointed some factors which have been impediments to revamping the agricultural sector in Nigeria. Besides, the attitude of many Nigerians is that agriculture is mainly for the illiterates and poor people. This is basically out of ignorance.

[12] studied the contributions of the agricultural sector to Nigeria's economic development between 1986-2007 using multiple regression to analyze the data. The result showed a positive relationship between Gross Domestic Product and domestic saving, government expenditure on agriculture and foreign direct investment. The outcome also denoted that $81 \%$ of the variation in GDP could be explained by Domestic Savings, Government Expenditure and Foreign Direct Investment.

The various regions in Nigeria are known for different agricultural production. Nigerian farmers are also into livestock production, fisheries, forestry and wildlife. The Northern part of the country is very good in cereal production such as sorghum, maize, millet, groundnut and cotton; the Middle Belt and the South have the potentials to produce root tubers such as cassava, yam, cocoyam and other crops such as plantain, palm oil, maize and so on ([18], [17]).

[19] in their study of the Nigerian economy: response of agriculture to adjustment policies embarked on the estimation of price and non-price supply response coefficients for nine individual crops, sub-sectorial aggregates and commodity exports using two-stage least square and seemingly unrelated regression method. They found, among others that the responses of food crops are sensitive to Nigeria's agro-climate and the traditional cropping patterns of Nigerian farmers, who are mainly smallholders. Besides, individual crops and sub-sectorial aggregates do not respond significantly to capital expenditure on agriculture, possibly due to action lags, weak choice of agricultural infrastructure and corruption. [20] in his study of the agricultural sector and Nigeria's development: comparative perspectives from the Brazilian Agro-Industrial Economy, 1960-1995 revealed that the successive Nigerian governments have only been paying lip service to agricultural development.

\section{Model Formulation And Specification}

There are some forms of agricultural practice in Nigeria, such as crop production (CP), livestock (LK), forestry (FT) and fishing (FS). Each is important in ensuring complete food production. Large scale production in each aspect is capital intensive. The increased activity in each of these forms of agriculture will play a role toward aggregate effect on the growth of Nigerian economy. Economic growth is often measured by real gross domestic product (RGDP). In this regard, it is pertinent to state that the functional form of the relationship of our concern is thus: RGDP $=\mathrm{f}(\mathrm{CP}, \mathrm{LS}, \mathrm{FT}, \mathrm{FS})$,

That is $\mathrm{RGDP}_{\mathrm{t}}=\mathrm{a}_{0}+\mathrm{a}_{1} \mathrm{CPt}+\mathrm{a}_{2} \mathrm{LS}_{\mathrm{t}}+\mathrm{a}_{3} \mathrm{FT}_{\mathrm{t}}+\mathrm{a}_{4} \mathrm{FS}_{\mathrm{t}}+\mathrm{e}_{\mathrm{t}}$

$$
\Delta \text { RGDP }_{\mathrm{t}}=\mathrm{a}_{0}+\mathrm{a}_{1} \Delta \mathrm{CPt}+\mathrm{a}_{2} \Delta \mathrm{LS}_{\mathrm{t}}+\mathrm{a}_{3} \Delta \mathrm{FT}_{\mathrm{t}}+\mathrm{a}_{4} \Delta \mathrm{FS}_{\mathrm{t}}+\square \mathrm{ECM}_{-1+} \mathrm{e}_{\mathrm{t}} \ldots
$$

$a_{0}$ is the intercept; $a_{1}, a_{2}, a_{3}$ and $a_{4}$ are the coefficients of the independent or the explanatory variables and $e_{t}$ is the stochastic error term. $\Delta$ is the first difference and $\square \square \square$ is the coefficient of the error correction termOn apriori basis, we expect the coefficients of the independent variables (equation 1) to have a positive relationship with the dependent variable. This is because if sufficient activity is taking place in agriculture, definitely the output will contribute meaningfully to tackle the problem of food insufficiency and raise the real income of the country. Equation 2 will be employed if there is evidence of co-integration.

\section{Sources of Data and Methodology}

The study is intended to use annual time series data from 1970 to 2009. It is the period in which a lot of programs, policies and strategies have been adopted to revamp agriculture in Nigeria. The study focuses on crop production, livestock, forestry and fishing. The data for the study was obtained from the Central Bank of Nigeria statistical bulletin (2009), volume 20. The study will start with test for stationarity and for long-run relationship. The method of ordinary least square (OLS) was also used for the data analysis. All tests were at 5\% level of significant.

\section{Test For Stationarity}

Unit root is a test for time series data to ascertain the stationarity of the variables. Non stationary series data suffers permanent or prolong effects from random shock. In order to ascertain the time series properties of the model variables we employed the Augmented Dickey- Fuller (ADF) and Phillips-Perron (PP) tests for stationarity. Our null hypothesis is that the variables have unit root that is not stationary while the alternative 
hypothesis does not have unit root or stationary. However, our decision rule is to reject the null hypothesis if the absolute value of the ADF statistic value exceeds the critical value at a chosen level of significant.

Table 1 Showing Augmented Dickey-Fuller and Phillips-Perron Unit Root Test Results.

\begin{tabular}{|c|c|c|c|c|c|}
\hline Variable & $\begin{array}{l}\text { ADF Statistic } \\
\text { Level }\end{array}$ & $\begin{array}{l}\text { PP Statistic } \\
\text { Level }\end{array}$ & $\begin{array}{l}\text { ADF Statistic } \\
1^{\text {st }} \text { difference }\end{array}$ & $\begin{array}{l}\text { PP Statistic } \\
1^{\text {st }} \text { difference }\end{array}$ & $\begin{array}{l}\text { Order of } \\
\text { integration }\end{array}$ \\
\hline RGDP & $\begin{array}{l}-3.610453^{*} \\
-2.938967^{* *} \\
-2.607932^{* * *} \\
(1.594591)\end{array}$ & $\begin{array}{l}-3.6067 * \\
-2.9378^{* *} \\
-2.26069^{* * *} \\
(1.782401)\end{array}$ & $\begin{array}{c}-3.615588^{*} \\
-2,941145^{* *} \\
-2.60906^{* * *} \\
(-5.422535)\end{array}$ & $\begin{array}{l}-3.6117 * \\
-2.9399 * * \\
-2.6080) * * *\end{array}$ & $\mathrm{I}(1)$ \\
\hline $\mathrm{CP}$ & $\begin{array}{l}-3.661661^{*} \\
-2.960411^{* *} \\
-2.619160^{* * *} \\
(5.734030)\end{array}$ & $\begin{array}{l}-3.6067 * \\
-2.9378^{* *} \\
-2.6069^{* * *} \\
(6.776962)\end{array}$ & & & $\mathrm{I}(0)$ \\
\hline LK & $\begin{array}{l}-3.610453^{*} \\
-2.938967 * * \\
-2.607932 * * * \\
(15.00758)\end{array}$ & $\begin{array}{l}-3.6067 * \\
-2.9378 * * \\
-2.6069 * * * \\
(14.14482) \\
\end{array}$ & & & $\mathrm{I}(0)$ \\
\hline FT & $\begin{array}{l}-3.632900^{*} \\
-2.948404 * * \\
-2.612874 * * * \\
(-3.632900)\end{array}$ & $\begin{array}{l}-3.6067 * \\
-2.9378 * * \\
-2.6069 * * * \\
(13.89237)\end{array}$ & & & $\mathrm{I}(0)$ \\
\hline FS & $\begin{array}{l}-3.670170 * \\
-2.963972 * * \\
-2.621007 * * * \\
(4.602363) \\
\end{array}$ & $\begin{array}{l}-3.6067 * \\
-2.9378 * * \\
-2.6069 * * * \\
(13.66199)\end{array}$ & & & $\mathrm{I}(0)$ \\
\hline
\end{tabular}

$*(* *) * * *$ denote Augmented Dickey-Fuller (ADF) and Phillips-Perron (PP) statistic at 1\%, 5\% and 10\% level of significant. Figures in brackets are the critical values of ADF and PP respectively. Source: Authors' E-view estimated results.

From the table only Real Gross Domestic Product (RGDP) is stationary at first difference while Crop Production (CP), output of Livestock (LK), output of Forestry (FT) and Fishing (FS) are stationary at level form. In this respect, the null hypothesis of no unit root (non stationary) was accepted for RGDP at level form of the variable but was rejected in 1st difference (that is stationary) while the null hypothesis of no unit root for $\mathrm{CP}, \mathrm{LK}, \mathrm{FT}$ and FS was rejected at level form. In other words, the four variables were integrated of order zero as can be seen from both ADF and PP test statistic and critical values at 1\%,5\% and 10\% level. Given the results, we suspected a long-run relationship between the dependent and independent variable (s) since they almost have same level of integration. So, we proceed to test for co-integration in order to ascertain the long-run relationship between the explanatory and independent variables.

\section{Co-Integration Test Result}

The Johansen co-integration test uses two statistics test namely: the trace test and the maximal Eigenvalue test. The first row in each of the table tests the hypotheses of no co-integrating relationship while the second row tests the hypothesis of one co-integrating relation and so on, against the alternative of full rank of co-integration. We present the results in table 2

Table 2: Co-integrating Test Result between RGDP and Components of Agric. output

\begin{tabular}{|l|l|l|l|l|}
\hline Eigenvalue & Trace Statistic & $\mathbf{0 . 0 5}$ critical value & Probability & Hypothesized No of CE (s) \\
\hline 0.834282 & 136.2658 & 69.81889 & 0.0000 & None * \\
\hline 0.676013 & 67.96211 & 47.85613 & 0.0002 & At most $1 * *$ \\
\hline 0.419616 & 25.13410 & 29.79707 & 0.1567 & At most 2 \\
\hline 0.110500 & 4.459590 & 15.49471 & 0.8632 & At most 3 \\
\hline 0.000262 & 0.009963 & 3.841466 & 0.9202 & At most 4 \\
\hline
\end{tabular}

$*(* *)$ denotes rejection of the hypothesis at $5 \%$ significance level.

Trace Statistic test indicates 2 co-integrating equation(s) at 5\% level of significance

Source: E-view estimated result performed by authors.

The above result denotes the existence of co-integration between the real gross domestic product (rgdp) and crop production, livestock $(\mathrm{lk})$, forestry $(\mathrm{ft})$ and fishing $(\mathrm{fs})$. It shows the rejection of null hypothesis of no cointegration and acceptance of the alternative of co-integration. So, the results suggest existence of a stable long run relationship between RGDP and components of agricultural output. 
Table 3: REGRESSION RESULT. Dependent Variable D $(\log ($ RGDP $))$

\begin{tabular}{|l|l|l|l|l|}
\hline Variable & Co-efficient & Std error & T-statistic & Probability \\
\hline $\mathrm{D}(\log (\mathrm{CP}))$ & -0.20717 & 0.88003 & -0.235414 & 0.8153 \\
\hline $\mathrm{D}(\log (\mathrm{LK}))$ & 0.393031 & 0.335108 & 1.172849 & 0.2493 \\
\hline $\mathrm{D}(\log (\mathrm{FT}))$ & 0,903204 & 0.255668 & 3.532723 & 0.0012 \\
\hline $\mathrm{D}(\log (\mathrm{FS}))$ & -0.102496 & 0.193185 & -0.530562 & 0.5993 \\
\hline $\mathrm{ECM}$ & $-7.00 \mathrm{E}-07$ & $6.04 \mathrm{E}-07$ & -1.158742 & 0.2549 \\
\hline $\mathrm{C}$ & -0.078294 & 0.104045 & -0.752497 & 0.4571 \\
\hline F-Statistic & 3.107782 & & & 0.020860 \\
\hline R- squared & 0.320193 & Durbin Watson & & \\
Adj R squared & 0.217123 & 1.863309. & & \\
\hline
\end{tabular}

Source: E-view estimated result conducted by authors.

From the result the coefficients of crop production and fishing are negatively signed which is contrary to our apriori expectation. This seems unrealistic given that the yearly output of crop production and fishing should not bring about reduction in aggregate income of the country. The coefficients of production of livestock and forestry impact positively on real gross domestic product which is in line with our apriori expectation. Among the variables, only forestry significantly influence real gross domestic product this is because its probability of 0.0012 is less than $5 \%$ level of significant. The combined effect of all the variables on real gross domestic product is statistically significant based on F-statistic; the 0.05 (level of significant) is higher than 0.021 , the probability of F-statistic. The Error correction model, although negative, it is very low and statistically insignificant as the probability is higher than the critical level of significant $(0.2549>0.05)$, and so adjustment of deviation of the explanatory variable back to normality is very slow. The coefficient of determination and its adjusted coefficient are $32 \%$ and $22 \%$ respectively, this means that about $68 \%$ and $82 \%$ of variation in the real gross domestic product are accounted for by variables other than agriculture. So, both are not strong showing weak relationship. The Durbin Watson test for serial autocorrelation shows evidence of no first order serial correlation since the Durbin Watson statistic of 1.86 is approximately to 2 .

\section{Discussion Of Results}

The results have shown the influence of agriculture on the real gross domestic product of Nigeria. The result does not contradict (Ugwu and Kanu, 2012) who point that agriculture contributes minimally during the period of study in terms of output, market, foreign exchange and capital formation or transfer as a result of policy instability, poor coordination of policies, poor implementation and mismanagement of policy instruments and lack of transparency. It further depicts that practical approach has not been given to the various policies, programmes and political promises of various leaders.

One would expect that aggregate crop production in Nigeria, given the number of subsistence farmers would make a great change. But the reverse is the case as low productivity by very large number is not sufficient to take care of the consumption level of over 150 million people. The significant impact of forestry on real gross domestic product can be attributed to availability of resources and so much is not needed to commence production and production is not only for personal use. The result further depicts that Nigeria is under utilizing her abundant fertile soil bestowed by nature which is supposed to help create more job opportunities and increase agricultural yield needed to sustain life, be source of industrial raw materials and increase employment of youths. It can also be deduce from the result that aggregate government expenditure in this direction aimed at tackling poverty is yet to achieve positive result given the continuous rise in poverty in Nigeria. It is difficult to accept that there is no diversion of resources allocated to this sector considering the impact it has on growth. In other words, corruption in Nigeria which exists virtually in every sector of the economy must have a role to play in hindering goal attainment. It is also plausible to mention that the high cost and stringent collateral requirement from farmers for loans by commercial banks has contributed to decline in agricultural practices since large scale production is capital intensive.

Besides, some farmers mainly operate on seasonal basis. This is due to insufficient resources to embark on irrigation or adopt mechanised farming and as such cannot produce more than subsistence. The recent insecurity and crisis in some parts of the country, especially in the Northern part of the country has its share of adversely affecting stable agricultural output production. It is our conviction that all these and among others have contributed to the insignificant impact of the components of agricultural output on economic growth of Nigeria measured by real gross domestic product (rgdp).

\section{Recommendations}

In consideration of the outcome of this study, it is undoubted that the necessary change in this sector is possible and can be attained if there is revival of thought pattern and attitudinal change of people of Nigeria. 
However, in our opinion, we hope the following points will help so much to revive agricultural practices in Nigeria.

(1) Integrated agriculture is in vogue and Nigeria should not be left out. It is imperative for the federal, state and local governments to establish integrated agriculture in all the wards in each local government as it exists in the Republic of Benin. Eighty percent of National Youth Corps members should be posted to such integrated farms every year which is a world of its own as it has all the essentials of living. This will really boast food production in Nigeria and help considerably to solve unemployment and excessive food importation in Nigeria.

2) Efforts should be commenced earnestly to tackle the hydra-headed problem of corruption in the country. Corruption has brought about disruption of the distribution of resources to various nooks and crannies of the country. Tackling corruption should be everybody's affair and not only the government. This is because, it has become a way for life of many Nigerians and all must be involved if a change is really needed.

3) Mostly required is the political will to fund, monitor and supervise the establishment of programmes designed to reposition agriculture in Nigeria. The issue of mere budget and allocation of resources have not been working over the years. The Ministry of Agriculture needs to co-opt communities when commencing a project so as to ensure that all resources allocated are put to work.

(4) There is the need to emulate the radical reform of food production adopted by the Chinese government. If China could feed her population of over 1.3 billion and still export food to the world, Nigeria has to learn and employ the "magic wand". The starting point is the sectorial and land use reforms.

(5) Civil servants should be encouraged to own integrated farms. Accessible loans should be provided by the commercial banks and it should be devoid of severe collateral requirement.

(6) The rural farm settlements and rural areas as a whole should be reformed by the provision of infrastructure and recreation facilities. This will go a long way to check rural-urban migration which has brought excessive pressure on the facilities in the urban centres.

(7) Adequate incentives should be made to attract both domestic and foreign investors into food production.

(8) Farmers all over the country should be encouraged through establishment of irrigation facilities to ensure all seasonal production of agricultural output in Nigeria.

\section{Conclusion}

In this paper, we have ascertained the effect of agriculture on Nigerian economy. It was obvious that many Nigerians are into one form of agricultural activity or the other but operating at subsistence level. Consequently, the sector has not been able to impact significantly on the wealth of the Nigerian economy. Mass production of agricultural output, although capital intensive is yet to gain ground in Nigeria and this is supposed to help put food on the table of the masses, reduce poverty and encourage export. This must be addressed. Besides, the inability to revive the rural areas where a large proportion of the people live has not helped matters and so many youths who are supposed to delve into agriculture in the rural areas prefer living in slums in the urban areas, thereby defacing the urban areas and raising social vices in such areas. All these anomalies can be addressed if adequate political will is radically employed to change the status quo.

\section{References}

[1] Central Bank of Nigeria, Statistical Bulletin, (Abuja: Research Department, 2009).

[2] N. O Adedipe Fluxes, Forces and flash flosses in Nigeria agriculture, University of Agriculture, Abeokuta, Alumni Association Lecture Series, 1999.

[3] Central Bank of Nigeria, Annual report, (Abuja: CBN, 2002)

[4] M.N. Agwu,, I. N Nwachukwu, and B.C. Okoye, B. C, Worsening Food Crisis in Nigeria: A Discourse on Bail-Out Options,' Sacha Journal of Environmental Studies, 1(1), 2011, 64- 68.

[5] P.A.Okuneye, Rising cost of food prices and food insecurity in Nigeria and its implication for poverty reduction, $C B N$ Economic \& Financial Review, .39(4), 1-15, 2001.

[6] P. A Okuneye, A. B. Aromolaran, M. T. Adetunji, T. A. Arowolo, K. Adebayo and I . A Ayinde, Environmental impacts of trade liberalization: the case of Nigeria's cocoa sub-sector.' paper presented at the 42nd annual conference of the Nigerian Economic Society, at the University of Port Harcourt, Nigeria. 28 - 31, August 2001.

[7] K. E. Uma, Population, agriculture, food and poverty in Nigeria: an overview, Abia Journal of Management Sciences, 3 (1), 178-194, 2007.

[8] E. J. Nwosu, The challenge of poverty in Nigeria, (Owerri: Skillman Publisher, 2000).

[9] O. M. Obadan, Poverty reduction in Nigeria: the way forward, Central Bank of Nigeria economic and financial review, 39( 4), 1-30, 2001 .

[10] F.O Ogwumike, An appraisal of poverty reduction strategies in Nigeria', Central Bank of Nigeria Economic and financial review 39( 4). 1-17, 2001.

[11] S.L. Sanusi, Growth Prospects for the Nigerian Economy, Convocation Lecture delivered at the Igbinedion University Eight Convocation Ceremony, Okada, Edo State,2010.

[12] O. Izuchukwu, Analysis of the contribution of agricultural sector on the Nigerian economic development, World Review of Business Research 1(1), 2011, 191-200.

[13] D. Torty, Strategy bz. establishing and managing small business as a strategy for economic empowerment and poverty eradication ( Lagos: Sky blue publication, 2004). 
[14] I.N. Medugu, Achieving Sustainable Agriculture in Nigeria: A Land-Use Policy Perspective Toyo Academic, Industry \& Culture Integration Tour, 10-19 December, Shibaura Institute of Technology, Japan, 2006.

[15] Central Bank of Nigeria, Statistical bulletin, (Lagos: Research Department, 1995).

[16] V. N. Ojeh, T. Orgho, and P.H John, Agriculture as an index of socio-economic development of Delta State of Nigeria' World Environment, 2( 4), 62-68, 2012

[17] D. S. Ugwu, and I. O. Kanu, Effects of agriculture reforms on the agricultural sector in Nigeria' Journal of African Studies and Development, 4(2), 2012, 51-59

[18] A. Abdullahi, Employment creation and opportunities in the agro-allied sub-sector: the case of cassava production, Central Bank of Nigeria Bullion Publication, 2003,27 (4), 10.

[19] M.I Kwanashie, Ajilima, and A. Garba, The Nigerian response of agriculture to adjustment policies (Nairobi: AERC, 1998)

[20] O. Ogen, The agricultural sector and Nigeria's development: comparative perspectives from the Brazilian agro-industrial economy, 1960-1995, Nebula, 4 (1), 184-194, 2007. 